\title{
COVID-19 Guidelines, Are You Serious?
}

\author{
Satyendra Kumar Tyagi ${ }^{1}$ \\ ${ }^{1}$ Department of Gastroenterology, Kailashi Super Speciality \\ Hospital, Meerut, Uttar Pradesh, India
}

\author{
Address for correspondence \\ Satyendra Kumar Tyagi, MD, \\ Department of Gastroenterology, \\ Kailashi Super Speciality Hospital, \\ 44A Saket, Meerut, UP 250001, India \\ (e-mail: drtyagi@gmail.com).
}

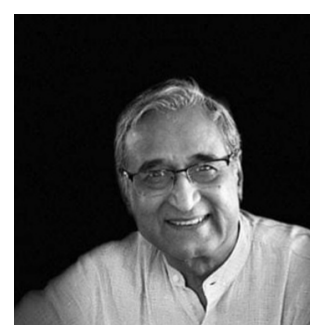

J Digest Endosc 2021;12:58.

To the Editor,

With reference to the Joint Guidance from Society of Gastrointestinal Endoscopy of India (SGEI), Indian Society of Gastroenterology (ISG), and Indian National Association for the Study of the Liver (INASL) for endoscopic procedures during the COVID pandemic published earlier in this journal, the major recommendation that these guidelines lay emphasis on is to defer routine endoscopic procedure "until the threat of coronavirus disease 2019 (COVID-19) lasts."

It is important to understand that there are no studies that have systematically looked at the type and frequency of aerosol generation during endoscopy, or of high transmission rates in endoscopy suites. ${ }^{1}$ On the contrary, recent data suggest low risk of COVID-19 transmission during safely conducted gastrointestinal endoscopy. ${ }^{2}$

Compared with usual practice, $75.4 \%$ of units were performing $<10 \%$ procedures as compared with pre-COVID-19 scare. Also, $86.9 \%$ of endoscopists themselves limited the number of procedures in accordance with the latest guidelines recommending avoidance of routine endoscopies. Almost 27.4\% of gastroenterologists doing endoscopic procedures are working in privately owned units or managing independent endoscopy units, ${ }^{3}$ and, as their endoscopic workload is primarily diagnostic and nonurgent, the current recommendations by ISG will put significant economic and legal strain on them.

Recommending stoppage of routine endoscopic procedures has other health consequences as well. The delay in

diagnosis due to markedly reduced endoscopies is likely to lead to potential increase of 33,890 excessive cancer deaths in the United States. ${ }^{4}$ This calls for an urgent rethink on the published SGEI guidelines.

It is imperative to follow strict infection prevention measures to protect both patients and personnel, yet the guidelines need not have recommended a drastic reduction in the number of endoscopic procedures. It is more logical to recommend a preprocedural COVID-19 reverse transcription polymerase chain reaction (RT-PCR) test for routine procedures, and a rapid COVID-19 antigen test for urgent procedures that cannot wait for the RT-PCR report.

\section{Acknowledgments}

No financial support received for this work.

\section{References}

1 Chiu PWY, Ng SC, Inoue H, et al. Practice of endoscopy during COVID-19 pandemic: position statements of the Asian Pacific Society for Digestive Endoscopy (APSDE-COVID statements) Gut 2020;69(6):991-996

2 Repici A, Aragona G, Cengia G. On behalf of the ITALIAN GI-COVID19 Working Group. Gut 2020;69:1925-1927

3 Goenka MK, Afzalpurkar S, Ghoshal UC, Guda N, Reddy N. Impact of COVID-19 on gastrointestinal endoscopy practice in India: a cross-sectional study. Endosc Int Open 2020;8(7):E974-E979

4 Lai A, Pasea L, Banerjee A, et al, Estimating excess mortality in people with cancer and multimorbidity in the COVID-19 emergency. doi : https://doi.org/10.1101/2020.05.27.200832s87

published online

October 31, 2020
DOI https://doi.org/

10.1055/s-0041-1726226 ISSN 0976-5042. (c)2020. Society of Gastrointestinal Endoscopy of India.

This is an open access article published by Thieme under the terms of the Creative Commons Attribution-NonDerivative-NonCommercial-License, permitting copying and reproduction so long as the original work is given appropriate credit. Contents may not be used for commercial purposes, or adapted, remixed, transformed or built upon. (https://creativecommons.org/licenses/by-nc-nd/4.0/).

Thieme Medical and Scientific Publishers Pvt. Ltd. A-12, 2nd Floor, Sector 2, Noida-201301 UP, India 